\title{
空気圧駆動を用いた力覚提示機能を有する多自由度鉗子の開発
}

\author{
只 野 耕太郎*1 住 野 亘*2 川 嶋 健 嗣*1
}

\section{Development of Pneumatically Driven Forceps Manipulator with Force Display}

\author{
Kotaro Tadano*1, Wataru Sumino*2 and Kenji Kawashima*1
}

\begin{abstract}
In this paper, a pneumatically driven forceps manipulator which is suitable for suturing task is developed. The manipulator has a wire drive rotating joint at the tip part and enables precise gripper rotation into practice. The gripper mechanism which consists of a small cylinder and slider-crank mechanism is proposed and implemented at the tip part. The gripper is driven by air pressure supplied through a fine tube so that the interference of other joints can be avoided. The gripping force of $20[\mathrm{~N}]$ is achieved. We constructed a master-slave system with the forceps manipulator and conducted some suturing experiments using a sponge object. It became clear that the forceps manipulator had good maneuverability and could estimate the external moment within the uncertainty of 10 [mNm].
\end{abstract}

Key Words: Pneumatics, Laparoscopic Surgery, Master-slave System, Force Feedback

\section{1. 緒言}

近年，外科手術に扔いて，患者の痛みの低減，入院期間の短 縮や傷跡の縮小などの QOL（Quality of Life）重視の観点か ら, 腹腔鏡手術が広く行われている [1] [2]. 腹腔鏡手術とは術 者が細い筒（トロッカ）から鉗子類を挿入し，内視鏡の映像を 観察しながら手術を行うものである. 開腹手術より傷口が小さ くて済むことから, 患者への負担が少ない. しかし, 腹壁を支 点として鉗子類を動かすために鉗子先端の自由度が不足し，高 度な技術を必要とする.

そこで, 術者の負担を軽減することを目的として, ロボット 技術により鉗子先端を多自由度化する研究が盛んに行われてい る [3]〜 [6]. 製品化されたマスタースレーブ方式の daVinci [7] が有名であり, 鉗子の遠隔操作が可能である, 直感的操作に優 れているなどの利点を有している，さらに，より正確で安全な 作業のために, 医師への力覚提示が望まれており, 鉗子先端付 近に力センサを用いた研究が行われている [8] [9]. しかし，小 型化，滅菌，較正など実用面を考慮すると鉗子への力七ンサの 取り付けは容易ではない。

筆者らは動力源に空気圧アクチュエータを用い，それらの内 部圧力から力七ンサを用いずに鉗子先端に㗢く外力を推定する ことが可能な鉗子マニピュレータの開発を進めてきた $[10][11]$.

原稿受付 2008 年 7 月 28 日

*1 東京工業大学

*2 (株) コマツ

${ }^{* 1}$ Tokyo Institute of Technology

${ }^{* 2}$ Komatsu Ltd.

ロ 本論文は学術性で評価されました。
しかしこれまでに開発した鈿子マニピュレータでは把持部への 動力伝達にワイヤを用いていたため, 強い把持力を発生した際 のワイヤ張力の増加に伴い, 他の屈曲関節に扔ける摩擦が増大寸 る問題があった.このため, 推定可能な最小トルクが $30[\mathrm{mNm}]$ に留まって抢り, 手術中の微細な反力を術者に提示するには不 十分であった，手術ロボットの適用範囲を広げるうえで重要な 手技の一つである縫合作業では, 針の刺入時に針が滑らない上 う強く把持する必要があるため, 外力推定精度への把持力の増 加による干渉を抑制することが求められる.

そこで本研究では, 縫合作業時の操作性拉よび外力推定精度 の向上を目的として, 新たに空気圧駆動の多自由度鉗子マニピュ レータの開発を行った. 本マニピュレータは先端に把持動作を行 う小型空気圧シリンダを内蔵することで, 他の関節との干渉を 排除したこと, 先端部に回転と屈曲を有する関節を配置し, 空 気圧シリンダの拮抗駆動によって動作を実現すること, 空気圧 アクチュエータの圧力から外乱オブザーバを用いて鉗子先端で の外力を力センサを用いることなく推定可能であることを特徴 としている.

本論文は 6 章から構成されており, 第 2 章では開発した鉗子 の概略を示し, 第 3 章では鉗子の駆動方法, 力の推定方法を述 べる. 第 4 章では実験によって力推定精度の検証を行い，第 5 章では模擬縫合作業を実施し, 開発した鉗子の有効性を明らか にする，最後に第 6 章で本研究をまとめる.

\section{2. 空気圧駆動多自由度鉗子の開発}

\section{1 設計指針}

鉗子を用いた縫合作業では湾曲針が細く滑りやすいため，強 


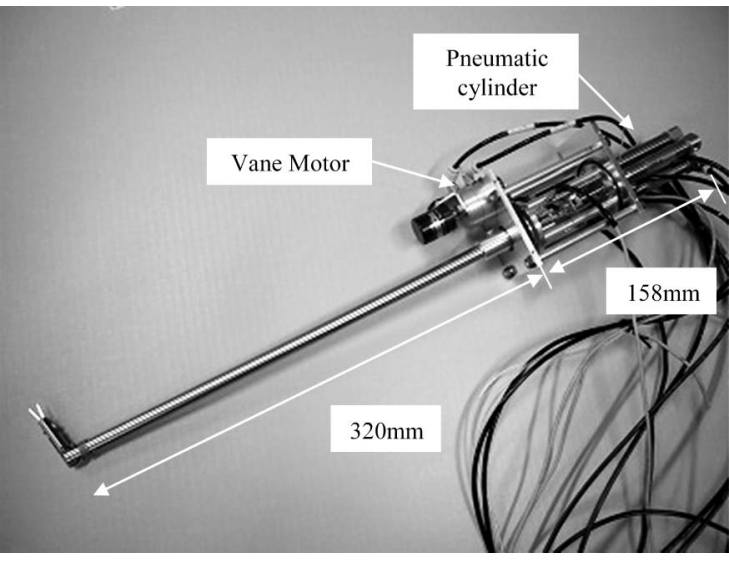

Fig. 1 Developed 4 DOFs forceps manipulator

力に把持しなければ組織と接触した際に滑って回転してしまい, 適切な角度で刺入することが困難である。 また，鉗子マニピュ レータの慣性や重力の影響を小さくするためには軽量化が望ま れる。これにより，鉗子マニピュレー夕を腹腔外で保持するロ ボットのアクチュエータや軸受け部への負荷が減少し, 逆動力 学モデルの誤差の影響を相対的に小さくすることができるため, 位置追従性と外力推定性能の向上が見込まれる。また，空気圧 アクチュエータのバックドライバビリティを利用した外力推定 を行う場合, マニピュレータが持つ静止摩擦力以下の外力はア クチュエータ内の圧力の変化を生じさせないため推定すること ができない. 外力推定の感度を高くするには，できる限り静止 摩擦力を低減することが重要である.ささらに, 静止摩擦力を小 さくすることはスティックスリップを低減し，良好な位置追従 性を得ることにつながる. よって, 以下に示す項目の実現を特 に念頭に置いて設計製作を行った。

（1）湾曲針を滑らないよう強く把持できるようにする

（2）できる限り軽量に製作する

(3) マニピュレータの摩擦力（特に静止摩擦力）をできる限り 小さく抑える

(4) 関節間の機構干渉をできる限り小さくする

（5）鉗子先端部に扔いて $4[\mathrm{~N}]$ 以上の力を発生可能とする

試作した多自由度鉗子マニピュレータの全体図を Fig. 1 に, 先端部を Fig. 2 に示す. 本鉗子マニピュレー夕は腹腔内で回転 2 自由度 $\left(\mathrm{J}_{1}, \mathrm{~J}_{3}\right)$, 屈曲 1 自由度 $\left(\mathrm{J}_{2}\right)$ と把持 1 自由度 $(\mathrm{ON}$. $\mathrm{OFF}$ のみ）を有している.

\section{2 把持部}

従来の多自由度鉗子ではワイヤによって把持部を駆動するも のがほとんどである。そのため, ワイヤが複数の関節をまたぐ ことから, 他の関節との干渉の懸念がある. 特に, 大きな把持力 を発生させる場合, 把持部操作用ワイヤの張力増加に伴い, そ れが通過する他の関節へ与える負荷も大きくなり, 摩擦などの 特性変化を招く。このような他関節との干渉なしに, 高い把持 力を得るために, Fig. 3 に示すような小型の空気圧シリンダと スライダクランク機構を組み合わせた把持機構を開発した。こ の把持部はシリンダ後方の穴につながれた外径 $1.0[\mathrm{~mm}]$, 内径 $0.5[\mathrm{~mm}]$ のポリエチレンチューブで高圧の空気を供給すること

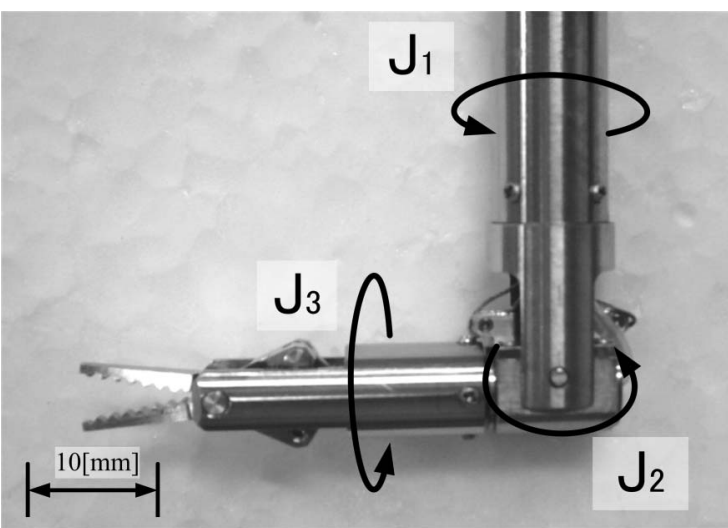

Fig. 2 Tip part of the forceps

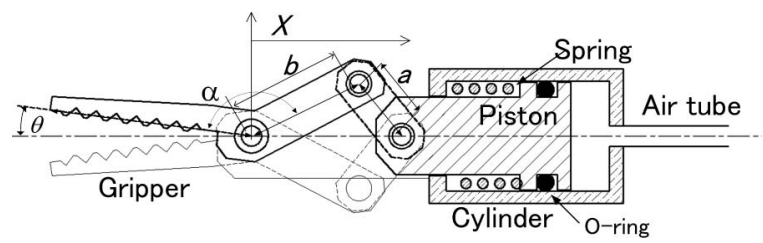

Fig. 3 Schematic drawing of gripper

によってシリンダを駆動する。グリッパを閉じる際にはシリン ダによる推力を用い，開く際にはバネの反力を用いている.

グリッパの角度 $\theta$ と, シリンダピストンの直動変位 $X$ との 関係は

$$
X=-b \cos (\theta+\alpha)+\alpha \sqrt{1-\left(\frac{b}{a} \sin (\theta+\alpha)\right)^{2}}
$$

である.ここで， $a, b$ は Fig. 3 に示すリンク長を， $\alpha$ はリンク の角度を表す。また，仮想仕事の原理より，グリッパを開閉す るためのトルク $\tau_{\theta}$ はシリンダの力 $F$ から以下のように求まる.

$$
\tau_{\theta}=\frac{\partial X}{\partial \theta} F=\left(b \sin (\theta+\alpha)-\frac{b \sin (\theta+\alpha) \cos (\theta+\alpha)}{\sqrt{1-\left(\frac{b}{a} \sin (\theta+\alpha)\right)^{2}}}\right) F
$$

縫合作業に用いる針はその直径が拉よそ $0.5 \sim 0.7[\mathrm{~mm}]$ 程度で あり，これを把持する際にグリッパの角度 $\theta$ は㧍よそ $1 ２$ [deg] と小さな值となる。 このとき, 式 (2) の括弧内第 2 項の分母が 0 に漸近するようにリンクパラメータ $a, b, \alpha$ を設計すれば, $\partial X / \partial \theta \rightarrow \infty$ と劣可動特異姿勢に漸近するため, シリンダの押 出力 $F$ が小さくても非常に大きな $\tau_{\theta}$ が得られる. 本試作機で は, 把持力や可動範囲, 機構のサイズを考慮し, Table 1 に示 すパラメータの通りに設計を行った。この場合，可動範囲のぎ りぎり外側である $\theta=-0.7[\mathrm{deg}]$ において, $\partial X / \partial \theta=\infty$ の 特異姿勢となる。

Fig. 4 に供給圧を $0.6[\mathrm{MPa}$ (gauge) $]$ としたときのグリッパ の角度とトルクの関係を示す. 湾曲針を把持した際にスライダ クランク機構が特異姿勢に漸近することで, 強力な把持力を発 生できることが分かる，本試作機では，グリッパがほぼ閉じた 
Table 1 Parameters of gripper

\begin{tabular}{|c|c|}
\hline Cylinder diameter & $6.5[\mathrm{~mm}]$ \\
\hline Cylinder stroke & $3.0[\mathrm{~mm}]$ \\
\hline Spring constant & $1.0[\mathrm{~N} / \mathrm{mm}]$ \\
\hline Link $a$ & $4.0[\mathrm{~mm}]$ \\
\hline Link $b$ & $7.1[\mathrm{~mm}]$ \\
\hline$\alpha$ & $146.5[\mathrm{deg}]$ \\
\hline
\end{tabular}

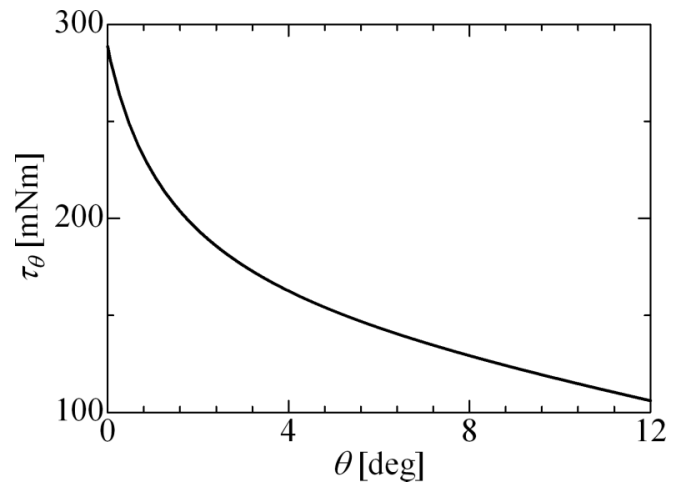

Fig. 4 Gripping torque

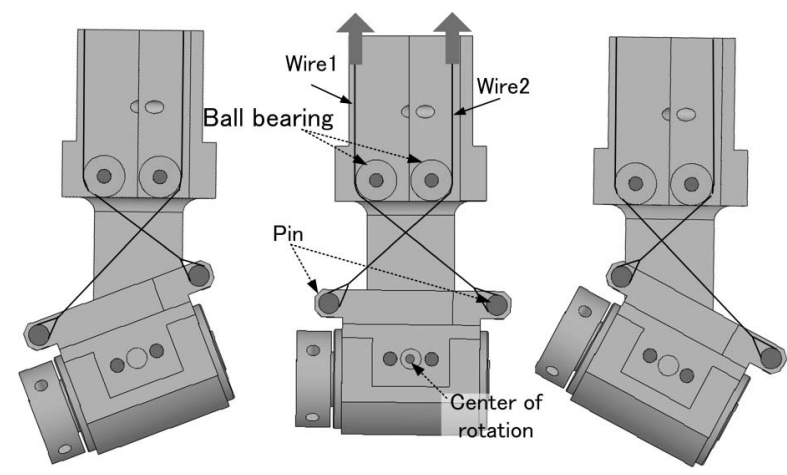

Fig. 5 Driving mechanism of $\mathrm{J}_{2}$

状態では $20[\mathrm{~N}]$ 以上の力で把持することができる．このように 強い把持力を発生させた場合でも, ワイヤなどで動力伝達を行 わないため，他関節への負荷が大きくならない.

また，シリンダから先の部分は容易に取り外すことができる ため，シリンダ内部を繰り返し洗浄することが可能である。こ のとき空気供給用のチューブは取り外して交換することができ る. O リングには耐熱性が高いフッ素ゴム材を用いているため, オートクレーブによる滅菌も可能である.

\section{3 先端関節部}

把持部に近接する関節 $\mathrm{J}_{2}, \mathrm{~J}_{3}$ は，駆動部に配置された空気 圧シリンダによりステンレスワイヤを用いて拮抗駆動される.

Fig. 5 に関節 $\mathrm{J}_{2}$ の構造を示す. ワイヤ末端はピンに固定さ れているが, 広範囲の屈曲角度において効率良く動力を伝達で きるようワイヤを交差させている，また，できるだけ低摩擦を 実現するために，ワイヤガイドにはボールベアリングを用いて いる.
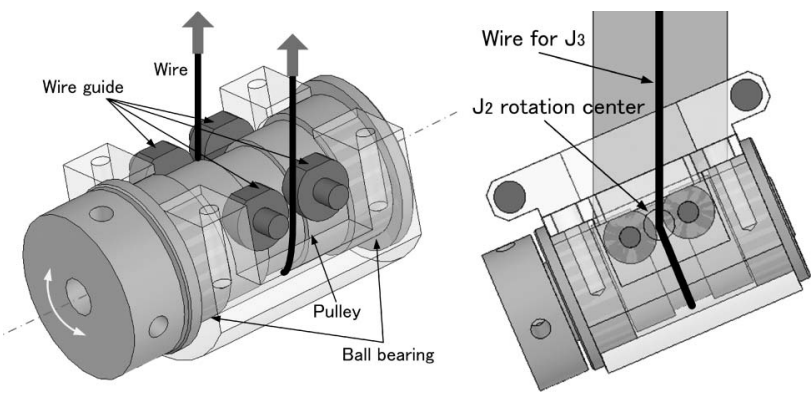

Fig. 6 Driving mechanism of $\mathrm{J}_{3}$

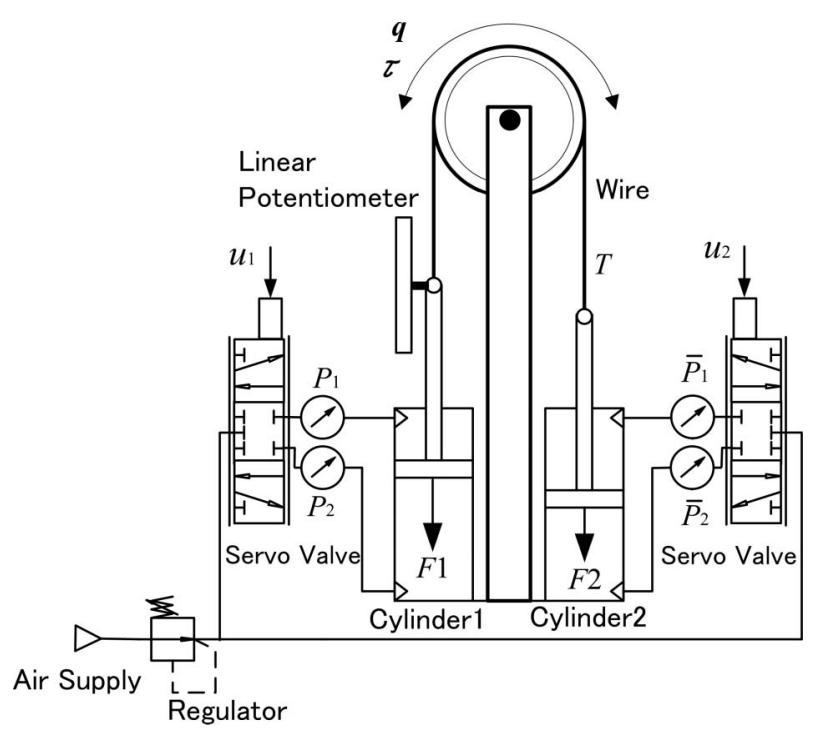

Fig. 7 Schematic drawing of tendon drive

関節 $\mathrm{J}_{3}$ では Fig. 6 に示すように, ワイヤは直径が $5[\mathrm{~mm}]$ のプーリに巻きつけられており， $\mathrm{J}_{2}$ との干渉を防ぐため $\mathrm{J}_{2}$ の 回転中心を通るよう拘束されている.

$\mathrm{J}_{1}$ は駆動部に取り付けられた空気圧摇動アクチュエータの 動力をタイミングベルトで伝達することにより駆動される． $\mathrm{J}_{2}$, $\mathrm{J}_{3}$ を駆動するシリンダを含むユニット全体を回転させるため, $\mathrm{J}_{1}$ の運動は $\mathrm{J}_{2}, \mathrm{~J}_{3}$ と完全に独立している.

鉗子軸の最大径は $11[\mathrm{~mm}]$ であり, 内径 $12[\mathrm{~mm}]$ のトロッカ を通過させることが可能である。トロッカ挿入時にはワイヤを 緩め, 関節 $\mathrm{J}_{2}$ が一直線上に伸びた状態にする. トロッカ通過 後に緩めていたワイヤを張ることにより， $\mathrm{J}_{1}$ と $\mathrm{J}_{3}$ の回転軸が それぞれ垂直となる状態の基準姿勢 (Fig. 2) へと移行する.

\section{4 システム構成}

把持部に近接する関節 $\mathrm{J}_{2}$ および $\mathrm{J}_{3}$ は Fig. 7 に示すように 二つの空気圧シリンダによって拮抗駆動される．空気压シリン ダには，低摩擦空気圧シリンダ（SMC，CJ2Q-30）を採用し， 変位はリニアポテンショメータによって計測する。

$\mathrm{J}_{1}$ の駆動には低速使用のシングルベーンモータ（KURODA, PRNAJ1D-90-45-X7）を用い, 回転角度はベーンモー夕に取 り付けられたエンコーダ (MTL Inc., MEH-12-2000PTS16) により計測する。

各関節の基準姿勢からの可動範囲および供給圧が 0.6 [MPa] 


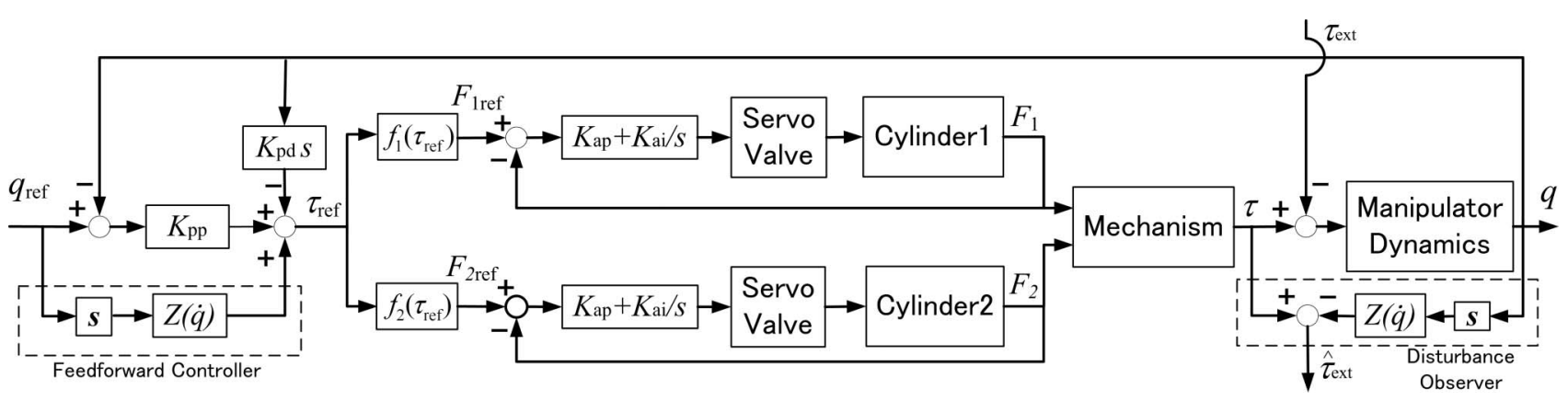

Fig. 8 Block diagram of control system

Table 2 Working range and maximum torque

\begin{tabular}{|c|c|c|}
\hline & Working range $[\mathrm{deg}]$ & Torque $[\mathrm{mNm}]$ \\
\hline$J_{1}$ & \pm 90 & 222 \\
\hline$J_{2}$ & $-40 \sim+50$ & 291 \\
\hline$J_{3}$ & \pm 100 & 85 \\
\hline
\end{tabular}

の場合における発生可能最大トルクを Table 2 に示す. このと き, マニピュレータ先端部で最大で $4.5[\mathrm{~N}]$ 程度の力を発生可能 であるが，減圧弁によりエアコンプレッサからの供給圧力を操 作することで，マニピュレータの最大発生力を容易かつ確実に 調節できる。また，使用したアクチュエー夕は低摩擦であるだ けではなく，同等の出力を有するものの中でも比較的軽量であ り, 鉗子マニピュレータ全体の重量を $500[\mathrm{~g}]$ 以下に収めている. 各空気圧アクチュエータはそれぞれ 5 ポートの空気圧サーボ 弁（FESTO，MPYE-M5-B SA）によって制御する. 本空気圧 サーボ弁は $100[\mathrm{~Hz}]$ 程度までの動作帯域を有しており, 最大で $0.9\left[\mathrm{~mm}^{2}\right]$ の有効断面積を得ることができる.なお現時点では, 把持部のシリンダには電磁弁を用いているが，今後これをサー ボ弁に置き換えることで，把持力を無段階に制御することがで き，柔らかい把持も実現可能である.

配管としては， $\mathrm{J}_{2}$ および $\mathrm{J}_{3}$ を駆動するシリンダには外径 $2[\mathrm{~mm}]$, 内径 $1.2[\mathrm{~mm}]$ のものを, $\mathrm{J}_{1}$ を駆動するベーンモータ には外径 $3.2[\mathrm{~mm}]$, 内径 $2[\mathrm{~mm}]$ のものを用いた. 管路長はいず れもおよそ $1.5[\mathrm{~m}]$ である. また, 圧力センサは半導体式の圧力 センサ（SMC，PSE510-R06）を用いた。測定レンジは $1[\mathrm{MPa}]$ であり, 数 $[\mathrm{kHz}]$ の動作帯域を有している. 制御用コンピュー 夕は OS R RTLinux を利用しており，1 [ms] の制御周期を実 現している。このような空気圧サーボシステムでは, 空気圧ア クチュエータとサーボ弁の間に電磁弁を配置し, 停電時や緊急 時にアクチュエータ内の圧縮空気を瞬時に排気するよう設定す ることで, 問題発生時にマニピュレータの駆動を直ちに停止す ることが可能である。

\section{3. 制御系の構成}

空気圧サーボシステムは空気の圧縮性や管路の影響による非 線形性を有しているが，位置制御系に駆動力制御ループを内包す ることによってその影響を改善できることが知られている [12]. 一般にカスケードループの動作帯域はメインループの動作帯域
よりも高くなければならない. 駆動力制御に用いたサーボ弁の 動作帯域は $100[\mathrm{~Hz}]$ 程度であるが, 外科医による手術手技を観 察した結果，腹腔鏡手術用鉗子マニピュレータに求められる動 作帯域は $2[\mathrm{~Hz}]$ 程度までと考えられるので, 駆動力制御による 非線形性の十分な補償が可能であると考えられる。

また，バックドライバビリティの高いマニピュレータでは，慣 性や摩擦, 重力の効果がその動作に大きく影響する。そのため 良好な位置追従性を実現するには逆動力学モデルによるフィー ドフォワード補償が必要となる。ささらに, 後に述べる外乱オブ ザーバによる外力推定を行う際にも, 逆動力学モデルは重要と なる.

鉗子マニピュレー夕先端の可動部の慣性および慣性モーメン 卜は十分に小さく, また手術作業の動作帯域は $2[\mathrm{~Hz}]$ 程度まで と考えられる。そのため動力学に拈いて重力や慣性モーメント による効果は無視できるほど小さく，摩擦による効果が支配的 であると考えられる。 また関節の角速度, 角加速度を求める際 には位置センサで計測した角変位を数值微分する必要があるが, 数值微分を繰り返すと計算精度が悪化する。位置センサとして リニアポテンショメータを用いている関節 $\mathrm{J}_{2}$ と $\mathrm{J}_{3}$ において特 にこのノイズの問題は顕著である。一方，各関節はお互いに干 渉しない構造となっている.よって, 鉗子マニピュレータの動 力学モデルを以下のような摩擦力のみのモデルとした.

$$
Z\left(\dot{q}_{i}\right)=C \dot{q}_{i}+D \operatorname{sgn} \dot{q}_{i}
$$

ここで, $C$ は粘性係数， $D$ はクーロン摩擦の大きさ， $q_{i}$ は関 節 $i$ の回転角度を表す.

以上により，本研究では拮抗駆動系に対して Fig. 8 のブロッ ク線図に示す制御系を構成した。位置と速度の偏差から関節周 りの駆動トルクを求める関節 PD 制御に, 逆動力学のフィード フォワード補償を加えた制御則である。関節 $\mathrm{J}_{2}$ と $\mathrm{J}_{3}$ は 2 本 のシリンダを拮抗させることにより駆動しているため，2 本の シリンダの出力する力の目標值 $F_{1 \mathrm{ref}}, F_{2 \mathrm{ref}}$ は, 関節トルクの 目標值 $\tau_{\text {ref }}$ に対して，以下のように計算した.

$$
\begin{aligned}
& F_{1 \text { ref }}=J \frac{\left|\tau_{\text {ref }}\right|+\tau_{\text {ref }}}{2}+T_{0} \equiv f_{1}\left(\tau_{\text {ref }}\right) \\
& F_{2 \text { ref }}=J \frac{\left|\tau_{\text {ref }}\right|-\tau_{\text {ref }}}{2}+T_{0} \equiv f_{2}\left(\tau_{\text {ref }}\right)
\end{aligned}
$$

ただし， $J$ は空気圧シリンダの直動変位から関節変位 $q$ までの ヤコビアンであり， $\mathrm{J}_{2}$ では $q_{2}$ の非線形関数， $\mathrm{J}_{3}$ では定数とな 
Table 3 Control parameters

\begin{tabular}{|cl|c|c|c|}
\hline & & $\mathrm{J}_{1}$ & $\mathrm{~J}_{2}$ & $\mathrm{~J}_{3}$ \\
\hline$K_{\mathrm{pp}}$ & {$[\mathrm{mNm} / \mathrm{rad}]$} & 1000 & 1000 & 100 \\
\hline$K_{\mathrm{pd}}$ & {$[\mathrm{mNms} / \mathrm{rad}]$} & 50 & 50 & 2 \\
\hline$K_{\mathrm{ap}}$ & {$[\mathrm{V} / \mathrm{N}]$} & 0.05 & 0.2 & 0.3 \\
\hline$K_{\mathrm{ai}}$ & {$[\mathrm{V} / \mathrm{Ns}]$} & 0.4 & 0.5 & 0.41 \\
\hline$C$ & {$[\mathrm{mNm} / \mathrm{rad}]$} & 28.0 & 15.0 & 1.5 \\
\hline$D$ & {$[\mathrm{mNm}]$} & 17.0 & 14.0 & 7.5 \\
\hline$T_{0}$ & {$[\mathrm{~N}]$} & - & 5.0 & 7.2 \\
\hline
\end{tabular}

る。また， $T_{0}$ は任意に設定可能なワイヤのバイアス張力であり， $T_{0}>0$ とすればシリンダや機構の摩擦およびワイヤの慣性が無 視できるという仮定のもとに, ワイヤがたるまないことが保証 される.これら駆動力の目標值 $F_{1 \mathrm{ref}}, F_{2 \mathrm{ref}}$ に対して, Fig. 8 に示すように PI 制御系を構成している. なお, 駆動力制御系 の帯域が $40[\mathrm{~Hz}]$ 程度あることを確認している [11].

さらに, 力七ンサを用いずに各関節周りに働く外力モーメン 卜を求めることを目的とし, 発生したトルク $\tau$ に対して, Fig. 8 の右側の点線で囲った部分に示すような外乱オブザーバを構成 した．各関節が持つ機械インピーダンスを表す関数 $Z(\dot{q})$ とア クチュエータによる関節周りのトルク $\tau$ を用いて, 関節周りに 働く外力モーメント $\tau_{\text {ext }}$ の推定值 $\hat{\tau}_{\text {ext }}$ は以下の式で計算する ことができる。

$$
\hat{\tau}_{\text {ext }}=\tau-Z(\dot{q})
$$

アクチュエータによる駆動トルク $\tau$ は空気圧シリンダの摺動摩 擦が十分小さいことから, 圧力を計測することによって求める ことが可能である.なお関節 $\mathrm{J}_{1}$ に対しては, Fig. 8 において $\tau_{\text {ref }}$ からの信号分岐がない形となる.

Table 3 に実験で用いた各制御パラメータをまとめる．機 械インピーダンス $Z(\dot{q})$ のパラメータ $C, D$ は, あらかじめ 無負荷において位置制御実験を行い同定し, 制御ゲイン $K_{\mathrm{pp}}$, $K_{\mathrm{pd}}, K_{\mathrm{ap}}, K_{\mathrm{ai}}$ およびバイアス張力 $T_{0}$ は良好な追従性が得 られるよう試行錯誤的に決定した。

\section{4. 外力推定実験}

\section{1 実験方法}

制御方法の有効性を確認するために, 鉗子先端部に治具によ り 6 軸力センサ（BL AUTOTEC.LTD, NANO2.5/2) を取 り付け，関節ごとに力センサの出力と外乱オブザーバによる外 力の推定值とを比較した. Fig. 9 に示すように, 力センサを取 り付けるために把持部を取り外して実験を行った。把持機構は $15[\mathrm{~g}]$ 程度と十分に軽量であり, また第 2 章で記述したように 本鉗子では把持部の開閉をチューブによって供給される高圧空 気によって行っているため，把持を行っても他関節との機構の 干渉が生じない。これらのことから，把持部を取り付けた実際 の使用時においても本実験とほぼ同じ推定精度を得ることがで きると考えられる。

外力推定の有効性を確認するために, 以下の 4 種類の条件下

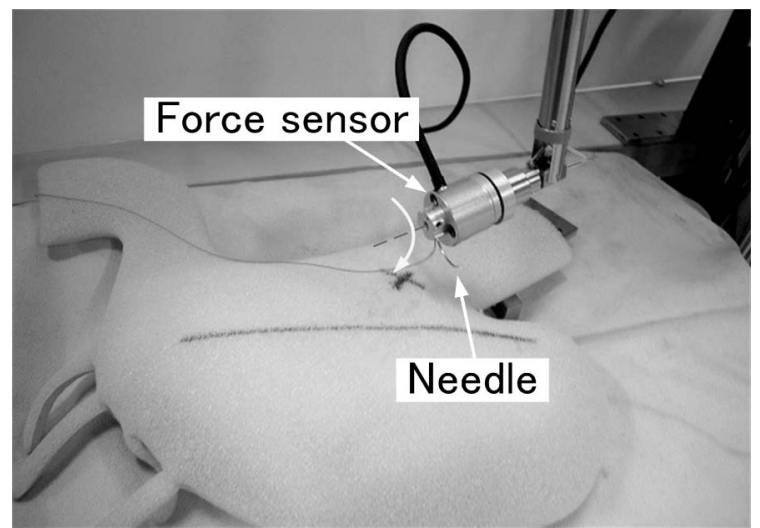

Fig. 9 Experimental situation of force evaluation

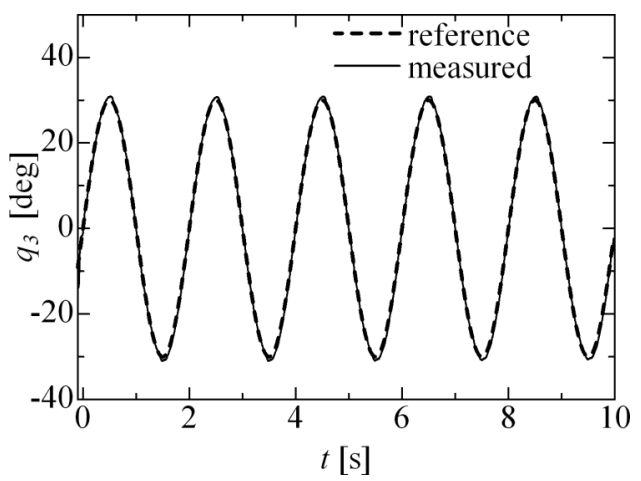

Fig. 10 Experimental results of position control $\left(\mathrm{J}_{3}\right)$

で実験を行った。

（1）関節を自由運動させる

（2）全関節の位置目標值を $0[\mathrm{deg}]$ とした状態で，カセンサに任 意の外力を加え，力センサを介して関節に外力を与える

（3）力センサを固定し, 各関節の一つに振幅が $30[\mathrm{deg}]$ の正弦 波状の位置目標值を与える

(4) 力七ン卅部に湾曲針を取り付け, 模擬縫合作業における針 の刺入動作を行う

\section{2 位置決め実験結果}

初めに, 外力の加わらない自由運動の状態で正弦波状の位置 目標值に追従させる実験を行った。関節 $\mathrm{J}_{3}$ の追従実験結果の 一例を Fig. 10 に示す．実験結果より，滑らかな動きが実現さ れており，スティックスリップ現象が発生しないことを確認し た。また，動摩擦による影響を補償するフィードフォワードの 効果により良好な追従性を実現できることが分かる．他の関節 も同様に良好な位置決め制御が実現できることを確認している。

ただし, Table 3 から明らかなように, 関節 $\mathrm{J}_{3}$ は他の関節 に比べ設定できる位置比例ゲインおよび位置微分ゲインが小さ い. 関節 $\mathrm{J}_{1}$ の駆動に用いているベーンモータはシール部分で 粘性摩擦が存在しており，これがダンパの役割を果たすことに よってゲインを高く設定することができると考えられる，屈曲 $\mathrm{J}_{2}$ と回転 $\mathrm{J}_{3}$ の駆動には同じ空気圧シリンダを用いているが, $\mathrm{J}_{3}$ は直径 $5[\mathrm{~mm}]$ のプーリによって直動を回転運動に変換して おり, ワイヤ張力と関節トルク間のヤコビアンが $2.5[\mathrm{~mm}]$ とな るのに対し, 屈曲 $\mathrm{J}_{2}$ のヤコビアンは角度によって変化するも 


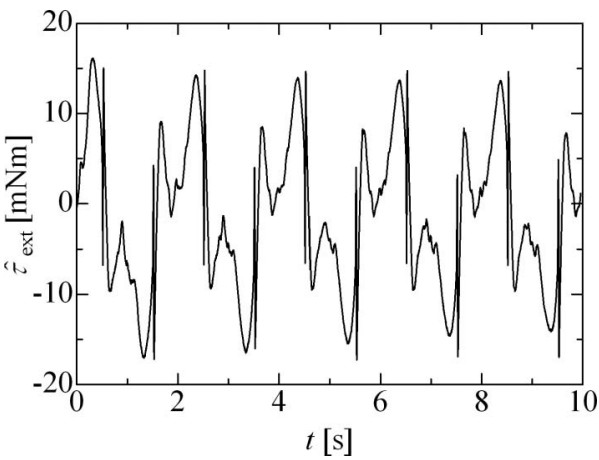

(a) $\mathrm{J}_{1}$

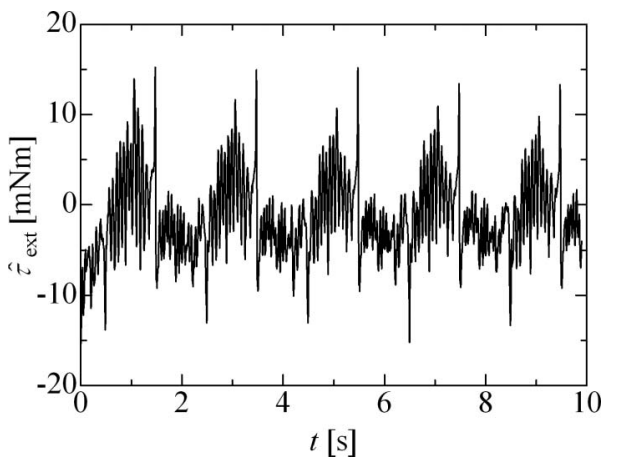

(b) $\mathrm{J}_{2}$

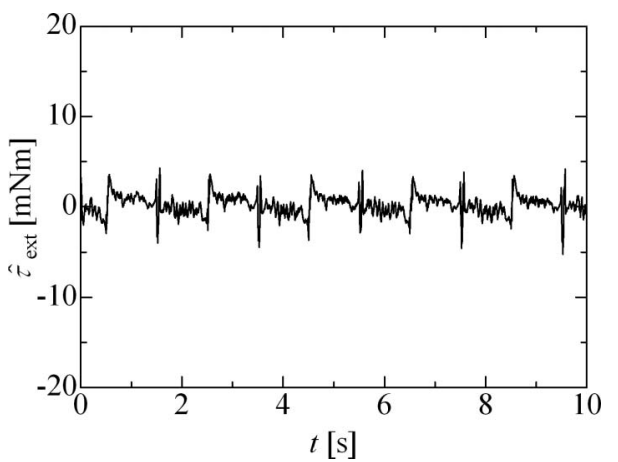

(c) $\mathrm{J}_{3}$

Fig. 11 Experimental results of torque estimation during free motion

のの, 可動範囲内において $5[\mathrm{~mm}]$ 以上の值となっている. 同 じ大きさの関節周りのトルクを出力する場合, 関節 $\mathrm{J}_{2}$ を駆動 するシリンダは $\mathrm{J}_{3}$ を駆動するシリンダの半分程度で済むため, $\mathrm{J}_{2}$ のほうが $\mathrm{J}_{3}$ よりも大きなゲインを設定できると考えられる.

\section{3 外力推定実験結果}

次に，外力による関節トルクを推定した結果を示す.

Fig. 11 は各関節をそれぞれ個別に自由運動させた際の実験 結果である. 外乱才ブザーバの出力である $\hat{\tau}_{\mathrm{ext}}$ は $0[\mathrm{Nm}]$ となる ことが理想であるが，実際にはFig. 11 のように関節 $\mathrm{J}_{1} ， \mathrm{~J}_{2}$ で は最大 $15[\mathrm{mNm}]$ 程度, $\mathrm{J}_{3}$ では最大 $7[\mathrm{mNm}]$ 程度の誤差が生 じていることが分かる.これは, 逆動力学モデルの誤差やモデ ルに含まれていない静止摩擦などの影響よるものと考えられる.

次に，4.1節で示した $(2)$ の条件での関節 $\mathrm{J}_{2}$ と $\mathrm{J}_{3}$ の実験 結果を Fig. 12 に示す. 力センサが出力した值と外乱オブザー バの推定值がよく一致していることが確認できる.

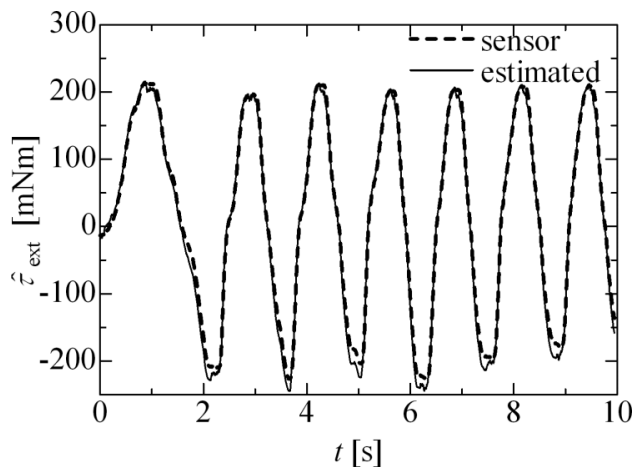

(a) $\mathrm{J}_{2}$

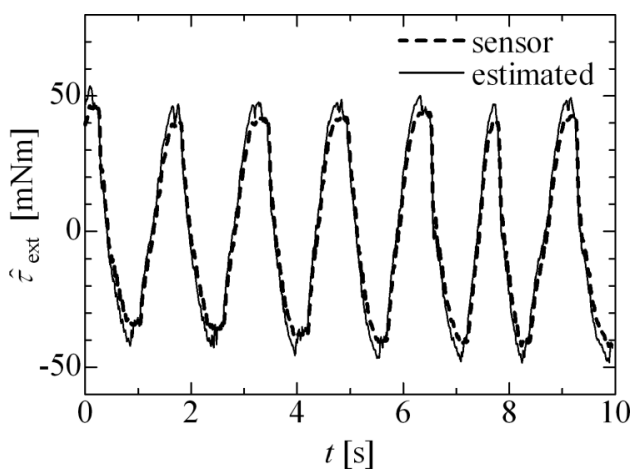

(b) $\mathrm{J}_{3}$

Fig. 12 Experimental results of torque estimation at the target angle $0[\mathrm{deg}]$

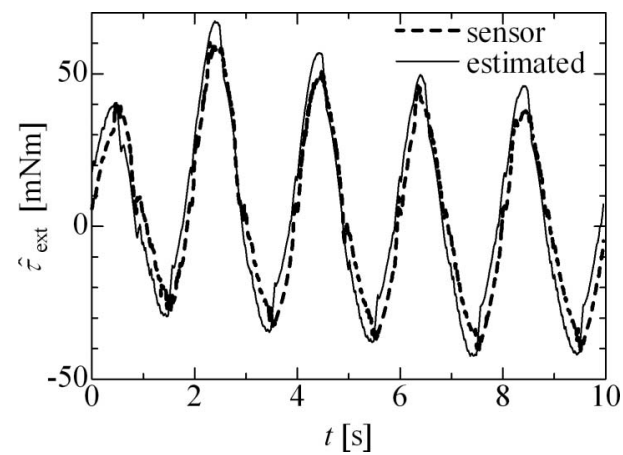

Fig. 13 Experimental results of torque estimation during sinusoidal target angle $\left(\mathrm{J}_{3}\right)$

また，Fig. 13 に 4.1 節で示した（3）の条件での実験結果の 一例として，関節 $\mathrm{J}_{3}$ の結果を示す。このとき， $\mathrm{J}_{3}$ にのみ正弦 波の位置指令を与え, 他の関節には $0[\mathrm{deg}]$ の位置目標值を与え た. Fig. 13 から推定值が力センサの出力值よりも大きくなる傾 向が見られる．この傾向は関節とアクチュエータ間に存在する 摩擦力が原因であると考えられる。アクチュエータによる駆動 力が関節に伝達するまでの過程で機構およびアクチュエータの 摩擦力によって減少してしまうため，実際に関節周りに発生さ れる駆動力はアクチュエータの差圧から推定した值よりも小さ くなる.

外力推定の精度をさらに向上させるためには機構およびアク チユエータが持つ摩擦力をさらに小さくする必要がある。また， 


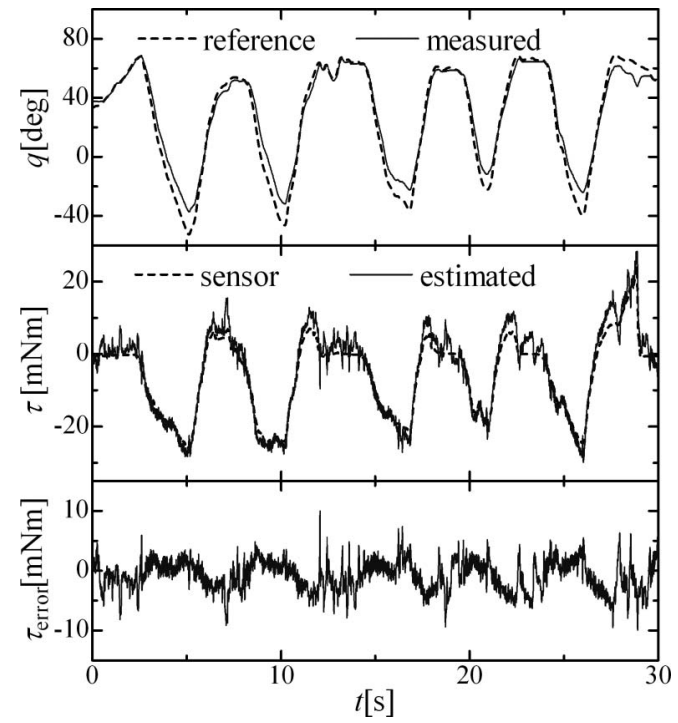

Fig. 14 Experimental results of torque estimate during suturing task with the force sensor

各関節に外力が加えられることによって軸受部などに負荷が生 じて静止摩擦力が増加したり, 動力学モデルが同定時から変化 することによっても外力推定精度が悪化する. そのため外力が加 わってもマニピュレータの機械インピーダンスが可能な限り変化 しないように設計を行う必要がある。しかし，上記の結果より， 全体として良好に力が推定可能であることが明らかとなった。

\section{4 縫合作業時の外力推定実験}

Fig. 9 に示したように鉗子マニピュレータ先端に力センサを 取り付け, 縫合作業時に図中の軸周りに生じるモーメントの推 定精度を確認した。湾曲針は力七ンサに固定されているため, 湾 曲針を臟器に刺入するまでの動作を行った。

Fig. 14 に関節 $\mathrm{J}_{3}$ の実験結果を示す. 上段に回転関節角度, 中段に外乱オブザーバを用いて推定した值とカセンサから算出 したトルク, 下段に力センサから求めたトルクと推定したトル クの差を示す. 実験では 30 秒間の間に 5 回模擬臟器への刺入 動作を行っている.

Fig. 14 の下段より, カセンサから算出したトルクと推定トル クの差は $10[\mathrm{mNm}]$ 以内に収まって抢り, 開発した空気圧駆動 の鉗子マニピュレー夕を用いて良好に外力が推定できているこ とが確認された. ただし, カセンサの出力が $0[\mathrm{mNm}]$ 近傍とな るときに, 推定外力は $10[\mathrm{mNm}]$ 程度の振幅で振動している.こ の振動は特に関節角速度が低速のときに大きく見られることか ら, 位置センサから求めた関節角速度の符号が変化し, 式 (3) に扔けるクーロン摩擦項の正負が頻繁に切り替わることによっ て生じていると考えられる.

これらの誤差による術者への不快感は, 推定した外力値を マスタへフィードバックする際に, 適切なローパスフィルタと $10[\mathrm{mNm}]$ 以下の信号は $0[\mathrm{mNm}]$ とするようなフィルタを通過 させることで，抑制できると考えられる，ただし，この場合シ ステムの力の感度は $10[\mathrm{mNm}]$ となり, それ以下の力を術者へ 提示することはできず，今後のさらなる改良が求められる。し かし, Fig. 14 から分かるように, 対象が模擬藏器ではあるが針

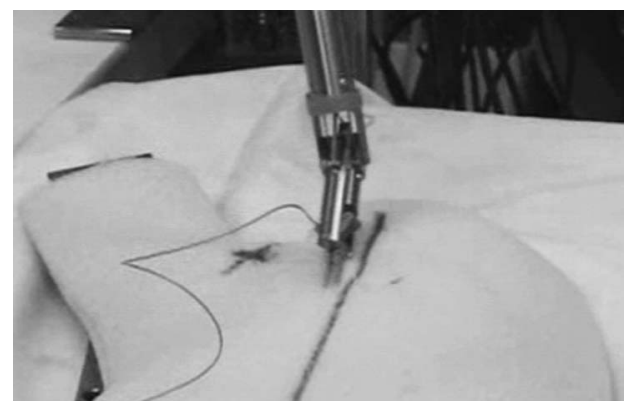

Fig. 15 Experimental view during suturing task with the gripper

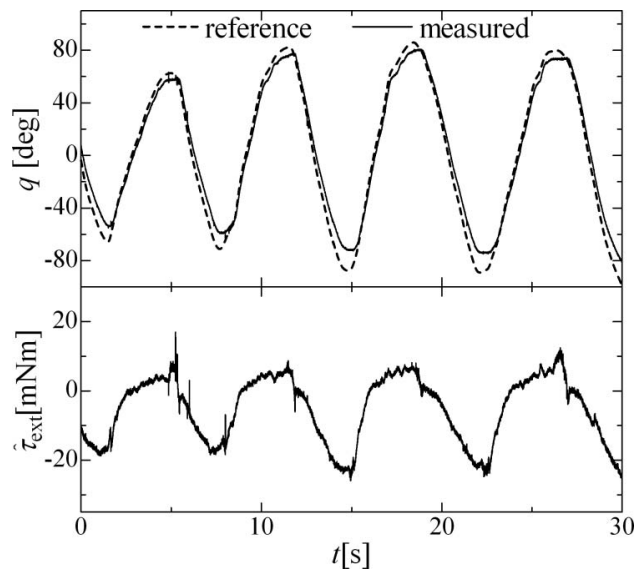

Fig. 16 Experimental results of torque estimate during suturing task with the gripper

を刺入する際の反トルクが $20[\mathrm{mNm}]$ 程度であり，このような 作業に执いても違和感なく力覚提示可能であると考えられる。

$\mathrm{J}_{1}, \mathrm{~J}_{2}$ に関しては，本実験ではほぼ静止した状態であったが, 自由運動における結果と同様に外力推定誤差は $15[\mathrm{mNm}]$ 以下 であった。

\section{5. 模擬縫合作業実験}

Fig. 14 では, 先端の把持部分は用いずに, カセンサ部に直接 湾曲針を取り付けて実験を行った，そこで，今回提案試作した 内蔵型小型空気圧シリンダによる把持機構の有効性を評価する ため, Fig. 15 のように力センサではなく実際に試作した把持 機構により湾曲針を把持して, 模擬臓器に対して縫合作業を実 施した。ここでは, Fig. 14 の実験と同等の条件とするため, 針 を模擬臓器に刺入するまでの動作を約 30 秒の間に 5 回行った. 関節 $\mathrm{J}_{3}$ の実験結果を Fig. 16 に示す. 上段に回転角度の変位, 下段に外乱オブザーバから推定したトルクを示す。この結果は Fig. 14 と同様の傾向を示して抢り, 試作した鉗子マニピュレー 夕および実装した外力推定方法の有効性が確認された。

\section{6. 結言}

本研究では, 腹腔鏡用鉗子システムとして, 外力推定精度お よび縫合作業時の操作性の向上を目指し, 空気圧駆動の 4 自由 度鉗子マニピュレータの開発を行った。本マニピュレー夕は先 端に把持動作を行う小型空気圧シリンダを内蔵することで, 他 
の関節との干渉を排除したこと, 先端部に回転と屈曲を有する 関節を配置し, 空気圧シリンダの拮抗駆動によって動作を実現 すること, 空気圧アクチュエータの差圧から外乱オブザーバを 用いて鉗子先端での外力を力センサを用いることなく推定可能 であることを特徵としたものである.

開発したマニピュレータを用いて模擬臓器の縫合作業を行っ たところ, カセンサから算出したトルクと推定トルクの差は関節 $\mathrm{J}_{3}$ において $10[\mathrm{mNm}]$ 以下, その他関節 $\mathrm{J}_{1}, \mathrm{~J}_{2}$ では $15[\mathrm{mNm}]$ 以下に収まっており，良好な外力推定精度を有することが確認 できた。

謝 辞 本研究を進めるに当たり, 東京工業大学香川利春教 授ならびに東京医科歯科大学田中直文先生, 小嶋一幸先生, 大 谷俊樹先生に貴重なご意見をいただいた。また，本研究の一部 は平成 19 年度科学研究費補助金若手研究（A）（No.18686023） により行われた。ここに謝意を表す。

\section{参 考 文 献}

[1] G.H. Ballantyne, P.F. Leahy and I.M. Modlin: LAPAROSCOPIC SURGERY. W.B. Saunders, 1994.

[2] 内視鏡外科の Basics, 日本内視鏡外科学会雑誌, vol.5, no.6, pp.569$647,2000$.

[ 3 ] 橋爪誠: “手術支援ロボットの現状と将来”, 日本ロボット学会誌, vol.22, no.4, pp.423-425, 2004

[4] R.H. Taylor and D. Stioianovici: "Medical Robotics in
Computer-Integrated Surgery," IEEE Trans. on Robotics and Automation, vol.19, no.5, pp.765-780, 2003.

[5] 山下紘正，金大永，波多伸彦，土肥健純：“多節スライダ・リンク機構 を用いた腹部外科手術用鉗子マニピュレータの開発”, 日本コンピュー 夕外科学会誌, vol.5, no.4, pp.421-427, 2004.

[6] K. Ikuta, T. Hasegawa and S. Daifu: "Hyper Redundant Miniature Manipulator Hyper Finger for Remote Minimally Invasive Surgery in Deep Area," Proceedings of the 2003 IEEE International Conference on Robotics and Automation, pp.1098-1102, 2003.

[7] Intuitive Surgical Inc: http://www.intuitivesurgical.com/ index.aspx

[ 8 ] S. Katsura, W. Iida and K. Ohnishi: "Medical mechatronicsAn application to haptic forceps," Annual Reviews in Control, vol.29, Issue 2, pp.237-245, 2005.

[9] C.R. Wagner, N. Stylopoulos and R.D. Howe: "The role of force feedback in surgery: Analysis of blunt dissection," Proc. of Tenth Symposium on Haptic Interfaces for Virtual- Environment and Teleoperator Systems, pp.68-74, 2002.

[10] 只野耕太郎, 川嶋健嗣：“空気圧サーボを用いた多自由度鉗子システ ムのバイラテラル制御”, 日本コンピュータ外科学会論文誌, vol.7, no.1, pp.25-31, 2005.

[11] K. Tadano and K. Kawashima: "Development of a Master Slave Manipulator with Force Display using Pneumatic Servo System for Laparoscopic Surgery," International Journal of Assistive Robotics and Mechatronics, vol.8, no.4, pp.6-13, 2007.

[12] 則次俊郎, 安藤文典, 吉川智之 : “ゴム人工筋の制御性能”, 日本機械 学会論文集 $(\mathrm{C}$ 編), vol.60, no.570, pp.193-198, 1994.

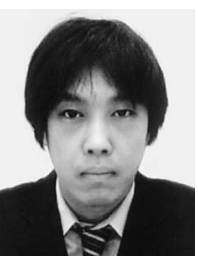

只野耕太郎 (Kotaro Tadano)

2007 年東京工業大学大学院総合理工学研究科博士 後期課程修了. 同年東京工業大学精密工学研究所研 究員. 2008 年同助教となり, 現在に至る.ロボット 工学の研究に従事. 博士 (工学). 日本機械学会, 計 測自動制御学会, 日本コンピュータ外科学会, IEEE 等の会員.

(日本ロボット学会正会員)

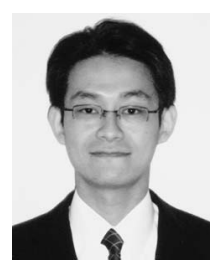

川嶋健嗣（Kenji Kawashima）

1997 年東京工業大学大学院理工学研究科博士課程 修了. 同年東京都立工業高等専門学校助手, 2000 年東京工業大学精密工学研究所助教授, 2007 年同 准教授となり，現在に至る。流体計測制御，ロボッ 卜工学の研究に従事. 博士 (工学). 日本機械学会, 計測自動制御学会, 精密工学会, IEEE 等の会員.

(日本ロボット学会正会員)

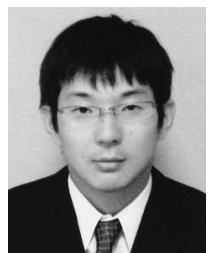

住野 亘（Wataru Sumino）

2008 年東京工業大学大学院総合理工学研究科修士 課程修了。同年株式会社小松製作所に入社し，現在 に至る. 油空圧機器の設計開発に従事. 日本機械学 会会員. 